\title{
Limited Nuclear Weapons Free Zone-Northeast Asia: Overview
}

\author{
By Bernard Gourley (USA)
}

\begin{abstract}
1 e concept of a nuclear weapons free area in Northeast Asia was conceived during the historic period of geopolitical change in 1991. Among the many auspicious events transpiring at the time were the reduction in US nuclear weapon missions and the development of denuclearization talks between the two Koreas. The earliest conception of the LNWFZ-NEA was of a body to facilitate the achievement of a nuclear-free Korean peninsula while building cooperative security in the broader region. After an initial period of plamning and gaining support for the project, the first presentation to an international audience was in March of 1992.

1993 saw the Democratic People's Republic of Korea (DPRK) amnounce its intentions to withdraw from the NPT, and this had a sobering effect on many in the intemational commuity. It raised concerns about to the ramifications of increased proliferation in Northeast Asia. In terms of the embryonic INWFZ-NEA, it had the effect of reducing opposition from the People's Republic of China (PRC) to such a zone -and this was a key development.

In 1995, a Senior Panel was created to oversee the formulation of a LNWFZ-NEA agreement. This body consisted of General officers from the militaries of China, Japan, the Republic of Korea (RoK), Russia, and the US. The panel was soon expanded to include officials from Argentina, Canada, Finland, France, and, a little later, Mongolia under the rubric of the Extended Senior Panel of the LNWFZ-NEA. It was during the mid-1990s that the proposed zone took elliptical shape stretching form Taiwan to Alaska, as opposed to the initial proposal of a circular zone in 1200 nautical miles in radius centered on the Korean Peninsula demilitarized zone. Recent years have seen a shift away from
\end{abstract}


geometrical boundaries to the placement a certain percentage of the tactical nuclear weapons of each of the nuclear weapon states on the chopping block.

Throughout the late 1990s, great efforts were taken to determine how to recognize a zone that included both nuclear and non-nuclear weapons states, and how momentum could be maintained in the push toward a nuclear weapons free zone. This led to the formulation of a three "basket" approach toward achievement of the zone. These baskets were: first, the structure, characteristics, and other details of the LNWFZ-NEA, second the confidence building measures necessary to provide an impetus for some participants to remain members in goodstanding.

The zone would be limited both with respect to geography and weapon systems. That is, it would not apply to the entire territory of some member states- notably China, Russia, and US, and it would apply only to tactical weapons. This has presented problems for the prospects of advancing the plan. First and foremost among these difficulties is that it would not be in accordance with the generally accepted definition of a nuclear weapons free zone. Such definitions require prohibition of all nuclear weapons (strategic as well as tactical) within all of the territory of the participating states. Many rail against the notion of a zone that would not include the most devastating of the weapons and that would only touch portions of some of the members.

What must be remembered is that the LNWFZ-NEA as it has been proposed is not meant to create the final once-and-for-all disposition of the question of nuclear weapons in the region. Instead, it is meant to break down intractable barriers into tractable hurdles.

Without a period in which relations are established and confidence built, those who seek an "all-or-none" outcome will perpetually end up with "none". The first Strategic Arms Limitation Talks (SALT I) resulted in an agreement that was weak on verification and put a number of nuclear weapon systems beyond consideration of the agreement, and it has been much decried in the arms control community as a poor agreement. On the other hand, START I is praised as a model of verification and "closed loop-holes." But what we must remember is that START I was built on confidence established under SALT I. I would agree that the two parties could not have gone straight to an agreement 
that required the degree of openness seen in the START I Treaty because they had not established the relationships necessary.

It is also important to remember that it is crucial to include the nuclear weapon states- China, Russia, and the United States- in the process of a Northeast Asia zone. There is a chain that must be considered. The nuclear status of the non-nuclear weapon states depends on the nuclear postures and doctrines of the nuclear weapon states. For example, Japan's continued willingness to forgo nuclear weapons is influenced by China's nuclear doctrine and posture; China's nuclear policy is influenced by Russia's and US's, and so on.

2001 saw the development if a draft treaty constructed by the members of the ESP that would be submitted for consideration by Track I negotiators.

As this decade has progressed, the members if the LNWFZ-NEA have watched the ups and downs of the Six-Party talks, and have been hopeful that they would be successful. The success of these talks would go a long way toward achieving the goals espoused by the Extended Senior Panel and would have a stabilizing effect on the region.

The most recent plenary meeting was in March of 2006 in Shanghai. This was the $10^{\text {th }}$ such session, not including a number of interim meetings. The 2006 plenary focused on consideration of confidence building measures; and it saw a number of breakthroughs.

First, Dr. Yang Xiyu of China's Foreign Ministry, who drafted the September 19, 2005 6-Party Talk statement, was able to attend and participate. Second, the US had an official observer from the State Department sitting in on the event. Finally, for the first time, the DPRK had a two-man delegation attend the meetings. In 2006, Dr. Endicott had two other interactions with representatives from the DPRK including a March meeting in New York with Ambassador Li Gun of the Ministry of Foreign Affairs, and a December visit to Atlanta by a two-man delegation headed by Minister Kim Myong Gil from the DPRK's UN mission.

I will conclude by speaking about the future of the LNWFZ-NEA. At present, plans are underway to hold the $11^{\text {th }}$ plenary meeting in Tokyo, Japan on October $1^{\text {st }}-3^{\text {rd }}$ of this year. The selection of Tokyo as a venue is meant to reiterate support for those who wish to continue Japan's policy of remaining a nuclear weapons free state. The October plenary 
will examine ways to maintain the viability of the INWFZ-NEA concept and its objectives, as well as creative means to give forward momentum to these efforts. The meeting will consider the relative merit of using the label "regional nonproliferation regime" versus "limited nuclear weapons free zone" to advance the objectives optimally. Also, Sam Nunn Research Fellow Michael Shannon will present research findings on the configuration of the verification regime that would be most politically, economically, and technically feasible for ensuring the legitimacy of the LNWFZ-NEA. Mike is a nuclear engineer with technical expertise in the science of verification who just finished the year long Seminar on Science, Technology, and International Security that teaches select scientists and engineers at Georgia Tech about policy development and analysis. 